In the course of four trials carried out in infected flocks the author wanted to test in the Muscovy duck the efficiency of the goose serum. Subcutaneous injection of I ml or even $0,5 \mathrm{ml}$ per individual during hatching gave good results, especially during the first four weeks.

Mortality almost disappeared compared to 16-30 p. Ioo according to the cases on the samples.

On the other hand, there was no action on the final weight of the ducks.

In spite of this interesting result, the use of a serum is not the future method which will allow to control the disease in question.

The real solution of this problem lies in the obtention of an efficient vaccine.

\title{
MAREK'S DISEASE IN BROILERS
}

\author{
J. P. WILLEMART \\ Laboratoires Roussel Sovetal-Licotal, \\ 92008 Paris, La Défense
}

The existence of Marek's disease in broilers is now well established in France under two clinical forms.

The first one is the same as that seen in pullets.

The second one is developing more slowly with low mortality. However, the losses are high because there is an important percentage of condemnations at slaughter due to the presence of severe cutaneous lesions. These are consisting mainly in hypertrophy of feathers and follicles, and thickening as well as discoloration of the skin. Nervous and visceral tumors are also present. In a sick flock, growth and feed conversions are severely altered.

Histological lesions are characterized by follicles and infiltrations made of lymphoïd cells.

The main problem of the diagnosis is the differenciation between cutaneous Marek's disease and leucosis. The nature of epidemiological lesions and the results of vaccination with a live T. H. V. vaccine prove that this disease is a special form of the Marek's disease.

\section{PATHOGENY OF AVIAN COCCIDIOSIS : BIOMETRICAL ANALYSIS AND EXPERIMENTAL STUDY OF NON SPECIFIC RESISTANCE}

\author{
J. AYCARDI et E. CHASLUS \\ Station de Pathologie aviaire, \\ Centre de Recherches de Tours, I. N.R. A., \\ Nouzilly, 37380 Monnaie
}

In experiments with E. tenella coccidiosis, biometrical analysis of the relations measured between coccidial inoculation, specific lesions and hemorrhagies, and general troubles as appreciated by depression of growth, food-consumption and food-efficiency, lead to the conclusions that 